\title{
Trisomy 12
}

National Cancer Institute

\section{Source}

National Cancer Institute. Trisomy 12. NCI Thesaurus. Code C36420.

A chromosomal abnormality consisting of the presence of a third copy of chromosome 12 in somatic cells. 